\title{
ACTIVENESS ANALYSIS LEARNS ELEMENTARY SCHOOL STUDENT ON ONLINE LEARNING DURING THE PANDEMIC
}

\author{
Trisno Yuwono ${ }^{1 *}$, Ana Andriani ${ }^{2}$ \\ Universitas Muhammadiyah Purwokerto, INDONESIA
}

Received 26 May 2021 - Revised 28 August 2021 • Accepted 20 September 2021

\begin{abstract}
The purpose of this study is to provide an insight of how active elementary school students learn in online learning during the Covid-19 Pandemic, as well as to identify the factors causing a lack of student learning activeness in online education. The research method used is literature study research. The data collection technique used is to collect theoretical studies and references from accredited articles and journals. This literature uses literature published in 2020-2021which can be accessed in full text in pdf format. The criteria for the articles reviewed are articles in Indonesian language research journals with the subject of student activity. Based on the results of literature research from several journals that have been written by previous researchers, it shows that in online learning, student activity is influenced by several factors, namely factors from teachers, parents, and students themselves. This literature review is based on material published between 2020 and 2021 that is publicly available. The criteria for the articles reviewed are articles on student activity in Indonesian language research journals. Based on the findings of previous researchers' literature searches from several journals, it is clear that in online learning, student activity is influenced by a variety of factors, even those from teachers, parents, and students themselves.
\end{abstract}

Keywords: Learning activeness, Student, Online Learning, Elementary School

\section{INTRODUCTION}

Education is a learning process to develop student activity and creativity with interactions that produce learning experiences. Education aims to prepare quality human resources who face the development of science and technology. The Covid-19 pandemic has had a tremendous impact on all aspects of life, especially in education. The real impact in the field of education is the obstruction of face-to-face learning due to large-scale social limitations and social distancing, which was appealed to by the government through Circular Number 4 of 2020 on March 24, 2020, containing the Implementation of Education Policies in an Emergency the Spread of Covid-19. The affects of the learning process, which initially turned face-to-face learning via distance, namely online (in a network). This policy was make in addition to smothering the spread of the Covid-19 virus and ensuring that students still have their right to learn and get teaching [1].

Online learning is distance learning by utilizing internet networks in the learning process. Online learning uses internet networks with accessibility, connectivity, flexibility, and the ability to generate various types of learning interactions [2]. Online learning is an educational innovation to answer the challenges of the availability of different learning resources. In the learning process, student and teacher interactions use online applications, such as WhatsApp, YouTube, zoom meetings, google classrooms, and other applications. The applications used are usually adjusted to the abilities of students and parents [3]. Teachers and students have to get used to it because in online learning, teachers must be able to use technology [4]. Teachers must find ways how to be still able to convey learning material and can be accepted readily by students.

Likewise, students are required to have mental readiness. The success of a model or learning media depends on the characteristics of the students. Learning activities can smoothly run if all the components that influence the process support each other. These components include students, teachers, curriculum, methods, facilities, and infrastructure, as well as the school environment [5]. Students are active subjects in learning. Student success in education influenc by the quality of the student's activity. Online learning requires students to be able to organize and direct themselves independently. The implementation of online learning also requires teachers to be more creative and innovative and all so pay attention to student characteristics so that all students can successfully achieve learning goals [4]. 
Activeness in learning is a state or thing that students can be active in education. Student learning activeness is one thing that must be considered by a teacher so that knowladge can be meaningful for all students [5]. The forms of student activeness in education can be seen from the involvement of students in the learning process, such as discussions, listening to explanations, solving problems, actively working on assignments to make reports, and being able to present report results [6]. Teachers must find ways to make learning exciting and make students less passive when the online learning process occurs [1]. With the active power of students in the learning process, students will be more likely to have a high sense of interest and enthusiasm in participating in teaching and learning activities [7].

The purpose of this literature study is to provide an overview of how active elementary school students learn in online learning during the Covid-19 Pandemic and to find out the factors that cause students' lack of active education in online education. At the same time the benefits of this research are as an evaluation to determine the appropriate methods and media for elementary school students in online learning during a pandemic.

\section{METHOD OF THE RESEARCH}

The inquire about strategy utilized in this research is to use the form of literature study or literature study. Method Literature study is a method by examining various journals and books that relate to the problem that we are going to study. Literature study also means a information collection technique by conducting a audit of book, writing, notes, and different reports related to the issue [8]. So, the literature study is not only meant to read the literature but to be more in-depth and critical of previous research that fits the topic.

This Literature Review uses literature published in 2020-2021 which can be accessed in full text in pdf format. The criteria for the articles reviewed are articles in Indonesian language research journals with the subject of student activity. The data collection method used is literature study, which is trying to find information approximately things or factors in notes, books, papers or articles, diaries, and news [9]. The information investigation method utilized is content analysis. In content analysis, text search is not just for theoretical and methodological studies, but content analysis at the same time utilizing the literature sources as material for the task. The research conduct by identifying the problems that occurred and then. Data were collected, analyzed, and concluded as needed, which might be a solution to the problem or in the form of a development strategy using literature study [10].

\section{RESULT AND DISCUSSION}

Table 1. Characteristic Results of Selected Articles

\begin{tabular}{|c|c|c|}
\hline Articles & Purposes & Result \\
\hline $\begin{array}{l}\text { Utilizing Ms. Teams to } \\
\text { Evaluate Student } \\
\text { Activities in Online } \\
\text { Learning During the } \\
\text { Covid-19 Pandemic } \\
\text { Afiani, K. D. A., \& } \\
\text { Faradita, M. N. (2021). }\end{array}$ & $\begin{array}{l}\text { To describe student } \\
\text { activities during } \\
\text { online learning using } \\
\text { Ms. Teams during the } \\
\text { covid-19 pandemic in } \\
\text { class IV SD } \\
\text { Muhammadiyah } 26 \\
\text { Surabaya. }\end{array}$ & $\begin{array}{l}\text { The results of research on student activities during online } \\
\text { learning using Ms.Teams during the covid } 19 \text { pandemic (1) } \\
\text { students pay attention to the material during live online } \\
\text { learning, (2) less students do not listen to teachers when online } \\
\text { learning takes place, (3) students do not ask questions at all. } \\
\text { During online learning, (4) students copy the material } \\
\text { provided by the teacher in online learning, and (6) students } \\
\text { are enthusiastic about participating in online learning from } \\
\text { the beginning to the end of the lesson accompanied by timely } \\
\text { attendance. Some of the constraining factors when learning } \\
\text { online are: (1) lack of awareness of parents or guardians of } \\
\text { students that online learning is very important, (2) limited } \\
\text { facilities owned by students, (3) unstable network conditions. }\end{array}$ \\
\hline $\begin{array}{l}\text { Possibilities to the } \\
\text { Process of Online } \\
\text { Learning } \\
\text { Activities } \\
\text { Elementary for } \\
\text { Students in the Covid- } \\
19 \text { Period } \\
\text { Saputra, N., Tobing, M. } \\
\text { T., \& Ili, L. (2021). }\end{array}$ & $\begin{array}{lr}\text { Analyzing } & \text { student } \\
\text { learning } & \text { activities } \\
\text { during } & \text { online } \\
\text { education during the } \\
\text { COVID-19 pandemic } \\
19 .\end{array}$ & $\begin{array}{l}\text { The results of the research show that during online education, } \\
\text { student education activity can't be achieved entirely in } \\
\text { accordance with the indicators of active learning. Barriers } \\
\text { during online learning are due to the lack of teaching aids and } \\
\text { limited internet access. }\end{array}$ \\
\hline $\begin{array}{lr}\text { Increasing } & \text { Student } \\
\text { Activity in } \begin{array}{r}\text { Online } \\
\text { Learning }\end{array} & \text { Through }\end{array}$ & $\begin{array}{l}\text { To find out the } \\
\text { increase in learning } \\
\text { activity in online }\end{array}$ & $\begin{array}{l}\text { Research Results Quiziz educational game media can increase } \\
\text { student activity in online learning during the prevention of } \\
\text { the spread of Covid-19 for social studies subjects. }\end{array}$ \\
\hline
\end{tabular}

Quiziz 2021 by the authors; licensee PGSD UMP. Phis article is an open access article distributed under the terms and conditions of the Creative Commons Attribution License (http://creativecommons.org/licenses/by/4.0/).

$\square$ trisnoyuwono10@gmail.com, ana.andriani@gmail.com (*Correspondence) 


\begin{tabular}{|c|c|c|}
\hline Articles & Purposes & Result \\
\hline $\begin{array}{l}\text { Game Media During } \\
\text { Covid-19 Preventing } \\
\text { the spread } \\
\text { Nurhayati, E. (2020). }\end{array}$ & $\begin{array}{l}\text { quiziz educational } \\
\text { game media. }\end{array}$ & \\
\hline $\begin{array}{l}\text { The Parent involvement } \\
\text { in Promoting Home } \\
\text { Learning Process } \\
\text { During a Pandemic } \\
\text { (Liliawati, A. 2021) }\end{array}$ & $\begin{array}{l}\text { Describe the role of } \\
\text { parents carried out to } \\
\text { support learning } \\
\text { activities in early } \\
\text { childhood education } \\
\text { in RA } \\
\text { Surabaya Scholar } \\
\text { Team. }\end{array}$ & $\begin{array}{l}\text { The results showed that (1) The role of parents in the } \\
\text { application of learning at home during the pandemic in } \\
\text { educating children includes mentoring and as a motivator. (2) } \\
\text { The impact of the role of parents on learning during the } \\
\text { pandemic at RA Team Cendekia Surabaya, parents facilitate } \\
\text { the involvement of learning activities in early childhood } \\
\text { education at RA Team Cendekia Surabaya. }\end{array}$ \\
\hline $\begin{array}{l}\text { Students' Learning } \\
\text { Independence in Online } \\
\text { Learning During the } \\
\text { Covid-19 Pandemic } \\
\text { (Hidayat, D.R, Rohaya, } \\
\text { A., Nadine,F., \& } \\
\text { Ramadhan, H., 2020) }\end{array}$ & $\begin{array}{l}\text { Get an overview of } \\
\text { learning } \\
\text { independence } \\
\text { teenagers doing } \\
\text { online learning }\end{array}$ & $\begin{array}{l}\text { The students (students/students) are not quite ready to learn } \\
\text { online, the cause is because of study habits, and less } \\
\text { supportive technology. }\end{array}$ \\
\hline
\end{tabular}

The similarities that can be found from the literature review of the five articles are about student learning activities during online education. While the differences in the results of the five articles, articles 1, 2 and 3 analyze student learning activities during the pandemic, while articles 4 and 5 analyze the factors that cause student learning activities from parents and students themselves.

Online learning that package with inappropriate learning models or methods can make students' understanding of the material very lacking. The results in low student activity and learning outcomes. Student learning activeness is an essential factor in assessing the quality of learning [16], because with active student learning, the learning objectives will easily achieve. Six factors influence learning activeness, namely 1) There is student involvement physically, mentally, emotionally, and intellectually in every learning process; 2) Students learn directly (experiential learning); 3) There is a desire of students to create a conducive learning climate; 4) The involvement of students in finding and utilizing every available learning resource that is considered relevant to the learning objectives; 5 ) The existence of student involvement in initiating initiatives; 6) The occurrence of interaction from various directions, both between students and students or between teachers and students [16].

The Covid-19 case, it has had a lot of influence on the learning process to affect the level of student learning activeness. The cause of low student learning activeness is due to obstacles and obstacles in the online learning process such as the means or tools used, internet networks, running out of internet packages, student motivation and support from parents, and piling up school assignments. This condition can trigger stress which causes students to be less enthusiastic about online learning [17]. Education considere less effective because the material not convey as a whole to students. The activities that are mainly carried out are simply providing materials and assignments and collecting assignments.

\section{CONCLUSION}

Based on literature review and the results of research studies of literature and research that have been carried out by previous researchers, it can be concluded that student learning activeness during the pandemic is influenced by several factors, namely factors from teachers, parents, and students themselves. The factors that become obstacles for teachers include the lack of creativity in the teachers in determining learning methods and media during the pandemic. In contrast, those from parents include: lack of motivation, not fulfilling children's learning needs/facilities maximally, and lack of collaboration with teachers. Then the obstacle factors that come from the students themselves include: the social background of the students who are less supportive such as economic, cultural factors or the opinion of the community who think online learning is only a burden so that students do not have high enthusiasm when online learning is carried out.

\section{REFERENCES}

[1] Kristin, F. Efektivitas Pembelajaran Jarak Jauh Dengan Menggunakan Aplikasi Zoom Dan Google Classroom Terhadap Keaktifan Belajar IPS Siswa Kelas 5 SD. Dari https://stkiprokania.ac.id/ejurnal/index.php/jpr/article/view/373 
[2] Sadikin, A., \& Hamidah, A. (2020). Pembelajaran Daring di Tengah Wabah Covid-19:(Online Learning in the Middle of the Covid-19 Pandemic). Biodik, 6(2), 214-224. Dari https://online-journal.unja.ac.id/ biodik/article/view/9759

[3] Marsen, C., Fimala, Y., \& Gistituati, N. (2021). Manajemen Kelas Virtual di Sekolah Dasar pada Masa Pandemi. Jurnal Pendidikan Tambusai, 5(1), 1600-1604. https://www.jptam.org/index.php/jptam/article/view/1145

[4] Halik, A., \& Aini, Z. (2020). Analisis Keaktifan Siswa dalam Proses Pembelajaran Daring di Masa Pandemi COVID-19. ENLIGHTEN: Jurnal Bimbingan Konseling Islam, 3(2), 131-141. Dari https://www.journal.iainlangsa.ac.id/index.php/enlighten/article/view/1887/1353

[5] Andriani, A., \& Wakhudin, W. (2020). Implementasi Pendidikan Karakter Melalui Model Pembelajaran Discovery Learning Di Mim Pasir Lor Karanglewas Banyumas. Jurnal Pengabdian Masyarakat, 1(2), 51-63. Dari https:/ / scholar.google.com/scholar?oi=bibs\&h l=id\&q=related:GRZhPL4HniEJ:scholar.google.com/

[6] Susmiati, E. (2020). Meningkatkan Motivasi Belajar Bahasa Indonesia Melalui Penerapan Model Discovery Learning dan Media Video Dalam Kondisi Pandemi Covid-19 bagi Siswa SMPN 2 Gangga. Jurnal Paedagogy, 7(3), 210-215. Dari https://e-journal.undikma.ac.id/index.php/pedagogy/article/view/2732/1932

[7] Naziah, S. T., Maula, L. H., \& Sutrisna, A. (2020). Analisis keaktifan belajar siswa selama pembelajaran daring pada masa covid-19 di sekolah dasar. Jurnal JPSD, 7(2), 109-120. Dari http://journal.uad.ac.id/index.php/JPSD/article/view/17327/pdf_64 ta

[8] Ahmad, J. (2018). Desain penelitian analisis isi (Content analysis). Research Gate, 5(9). https://www.researchgate.net/profile/Jumal-Ahmad/publication/325965331_Desain_

Penelitian_Analisis_Isi_Content_Analysis/links/5b305090a6fdcc8506cb8b21/Desain-Penelitian-Analisis-IsiContent-Analysis.pdf

[9] Ida, F. M., \& Maksum, H. (2021). Contribution of Learning Style, Learning Creativity and Exploratory Interest to Students' Simulation and Digital Communication Learning Outcomes during the Covid-19 Pandemic. Journal of Education Technology, 4(4), 404-414

[10] Dewi, W. A. F. (2020). Dampak Covid-19 terhadap implementasi pembelajaran daring di Sekolah Dasar. Edukatif: Jurnal Ilmu Pendidikan, 2(1), 55-61 dari https://www.edukatif.org/ index.php/edukatif/article/view/89/pdf tanggal 26 Mei 2021 MIRZAQON T, A. B. D. I. (2017). Studi Kepustakaan Mengenai Landasan Teori dan Praktik Konseling Expressive Writing. Jurnal BK Unesa, 8(1). Dari https://jurnalmahasiswa.unesa.ac.id/index.php/jurnal-bk-unesa/article/view/22037/20201

[11] Afiani, K. D. A., \& Faradita, M. N. (2021). Analisis Aktivitas Siswa dalam Pembelajaran Daring Menggunakan Ms. Teams pada Masa Pandemi Covid-19. Jurnal Pemikiran dan Pengembangan Sekolah Dasar (JP2SD), 9(1). Diunduh dari https://ejournal.umm.ac.id/index.php/jp2sd/article/view/15971/9572

[12] Saputra, N., Tobing, M. T., \& Ili, L. (2021). Strategi Pembelajaran Daring Sebagai Alternatif Proses Aktivitas Belajar Siswa SD Di Masa Covid-19. NATURALISTIC: Jurnal Kajian Penelitian Pendidikan dan Pembelajaran, 5(2b), 911-920. Diunduh dari https://journal.umtas.ac.id/index.php/naturalistic/article/view/1221/660

[13] Nurhayati, E. (2020). Meningkatkan keaktifan siswa dalam pembelajaran daring melalui media game edukasi quiziz pada masa pencegahan penyebaran covid-19. Jurnal Paedagogy, 7(3), 145-150

[14] Lilawati, A. (2020). Peran orang tua dalam mendukung kegiatan pembelajaran di rumah pada masa pandemi. Jurnal obsesi: Jurnal pendidikan anak usia dini, 5(1), 549-558. https://obsesi.or.id/index.php/obsesi/article/view/630/pdf

[15] Hidayat, D. R., Rohaya, A., Nadine, F., \& Ramadhan, H. (2020). Kemandirian belajar peserta didik dalam pembelajaran daring pada masa pandemi COVID-19. Perspektif Ilmu Pendidikan, 34(2), 147-154. http://journal.unj.ac.id/unj/index.php/pip/article/view/17184/9448Arikunto, S. (2010). Prosedur Penelitian Suatu Pendekatan Praktik. Rineka Cipta hal 234

[16] Handoko, B., \& Nurulisah, A. (2020). Perbandingan Tingkat Keaktifan Belajar Sebelum dan Sesudah Wabah Covid-19 pada Mahasiswa Prodi Administrasi Rumah Sakit Angkatan 2019 di STIKes Awal Bros Pekanbaru. Journal of STIKes Awal Bros Pekanbaru, 1(2), 38-42. dari https://ojs.stikesawalbrospekanbaru.ac.id/index.php/jsabp/article/view/46

[17] Sasanti, R. D. (2020). Pengajuan Masalah Berbantuan Edmodo Sebagai Upaya Meningkatkan Keaktifan Siswa Di Era Pandemi Covid-19. Euler: Jurnal Ilmiah Matematika, Sains dan Teknologi, 8(2), 60-69. Dari http:/ / ejurnal.ung.ac.id/index.php/Euler/article/view/10417/2853

\section{http://jurnalnasional.ump/index.php/dinamika}

